\title{
Flow cytometric determination of genome size in European sunbleak Leucaspius delineatus (Heckel, 1843)
}

\author{
Marta Filipiak • Grzegorz Tylko • \\ Wincenty Kilarski
}

Received: 9 November 2010/Accepted: 13 May 2011/Published online: 26 May 2011

(C) The Author(s) 2011. This article is published with open access at Springerlink.com

\begin{abstract}
The aim of this study was to compare DNA content in hepatocyte and erythrocyte nuclei of the European sunbleak, Leucaspius delineatus, in relation to nuclear and cell size by means of flow cytometry and fluorescence microscopy. The DNA standards, chicken and rainbow trout erythrocytes, were prepared in parallel with both cell types, with initial separation of liver cells in pepsin solution followed by cell filtering. Standards and investigated cells were stained with a mixture of propidium iodide, citric acid, and Nonidet P40 in the presence of RNAse, and fluorescence of at least 50,000 nuclei was analyzed by flow cytometry. Average cell size was determined by flow cytometry, using fresh cell suspension in relation to latex beads of known diameter. The size of nuclei was examined on the basis of digital micrographs obtained by fluorescence microscopy after nuclei staining with DAPI. The sunbleak's erythrocyte nuclei contain $2.25 \pm 0.06 \mathrm{pg}$ of DNA, whereas the hepatocyte nuclei contain $2.46 \pm 0.06 \mathrm{pg}$ of DNA. This difference in DNA content was determined spectroscopically using isolated DNA from the two cell types. The modal diameters of the erythrocytes and hepatocytes were estimated to be $5.1 \pm 0.2$ and $22.3 \pm 5.0 \mu \mathrm{m}$,
\end{abstract}

M. Filipiak · G. Tylko · W. Kilarski ( $₫)$

Department of Cytology and Histology, Institute

of Zoology, Jagiellonian University, 6 Ingardena, 30-060

Krakow, Poland

e-mail: wincenty.kilarski@uj.edu.pl respectively, and the corresponding modal dimensions of their nuclei (measured as surface area) were 15.2 and $21.4 \mu \mathrm{m}^{2}$, respectively. The nucleoplasmic index, as calculated from diameters estimated from surface area of nuclear profiles, was 2.51 for the erythrocytes compared with 0.08 for hepatocytes.

Keywords DNA content - Teleost - European sunbleak - Leucaspius delineatus red blood cells . Hepatocytes

\section{Introduction}

Flow cytometry is a well-recognized technique for nuclear DNA content analysis. It has gained an increasing use in DNA measurements in fish tissues for its speed, accuracy, and reproducibility. A flow cytometric analysis performed on a large number of fluorescent-stained fish nucleated erythrocytes has proven to be an ideal tool for DNA content and ploidy determinations (Vinogradov 1998; Lamatsch et al. 2000; Ciudad et al. 2002; Peruzzi and Chatain 2003; Hickey and Clements 2005; Juchno et al. 2010).

Genome size is an elementary factor of a given species. Since the function of repetitive DNA, which comprises the greater part of the eukaryotic genome, is still unknown, the biological significance of 
genome size remains far from being understood. The genome size is reported to correlate positively with cell and nuclei size in Cobitis taxa (Boron 1994, 2003). The correlation between ploidy level and both cell and nuclear size in erythrocytes was first reported by Swarup (1959) in the stickleback, Gasterosteus aculeatus L., and their artificially induced triploid individuals. Pie et al. (2007) in their elegant study pointed out several areas of evidence suggesting that both genes and whole genome duplication play a fundamental role in adaptive evolution (CastilloDavis et al. 2004; Le Comber and Smith 2004) and in the establishment of reproductive isolation (Lynch and Force 2000; Taylor et al. 2001).

Far-reaching studies on the genome size of teleosts have been published in the past (Hinergardner 1968; Hinergardner and Rosen 1972). Vinogradov (1998) presented an extensive study on genome size of 154 vertebrates, among which 39 European and South American fish species were included, whereas Fenerich et al. (2004) reported the DNA content in 20 species of Siluriformes from Neotropical waters. The collected and analyzed facts suggested that polyploidy could be involved in the process of speciation in the representatives of the fish order Siluriformes, though other mechanisms involving structural chromosome rearrangements, deletions, and duplications were not excluded. The key database of animal genome size is given by Gregory et al. (2007). Recently, Hickey and Clements (2005) described genome size evolution in New Zealand triplefin fish (Tripterigidae). They also derived the evolutionary relationship of these species based on DNA sequence data. However, they did not suggest polyploidy as a mechanism responsible for speciation in New Zealand triplefins.

The sunbleak is evolutionary diploid, with $2 n=50$ chromosomes, and lives in large schools in fresh waters, shallow ponds, lakes, and small rivers. It may inhabit isolated ditches of low oxygen content. The high RBC index of this species (Homatowska et al. 2002) is a very valuable strategic feature that allows the fish to survive in unfavorable oxygen conditions in its natural environment. Because of the size of the sunbleak (max. $12 \mathrm{~cm}$ in length), it is frequently kept in aquaria or bred in small garden ponds as an ornamental fish.

The aim of the present study was to estimate the nuclear DNA content in the sunbleak by flow cytometry, since the chromosome number of this species is established. The amount of DNA from erythrocyte nuclei was further compared with that from hepatocyte nuclei to determine variations in hepatocyte DNA content, where polyploidy frequently occurs. Additionally, sizes of both cell types as well as dimensions of their nuclei were estimated to calculate nucleoplasmic ratio. So far, most of the studies reported in the literature were carried out on erythrocyte nuclei only and one on retinal cells (Ciudad et al. 2002), liver cells (Juchno et al. 2010), or dorsal fin tissue nuclei (Lamatsch et al. 2000).

\section{Materials and methods}

\section{Animals}

The fish were collected during the last 2 years from the population inhabiting a small garden pond over the last 12 years. The living animals were transported to the laboratory and maintained in a well-aerated full glass aquarium until used. Before the experiment, fish were anesthetized in MS 222 solution (ethyl 3-aminobenzoate methanesulfonate salt, cat. no. A5040, Sigma-Aldrich) and then measured and weighed. Average length and weight of the fish (mean \pm SD) were $96.6 \pm 9.8 \mathrm{~mm}$ and $4.7 \pm 0.9 \mathrm{~g}$, respectively.

\section{Blood samples}

The DNA contents in erythrocyte and hepatocyte nuclei from Leucaspius delineatus were calculated on the basis of external standards: chicken erythrocytes (CE) and rainbow trout (Oncorhynchus mykiss) erythrocytes (TE) obtained from the hatchery of the Agricultural University of Krakow. The TE standard (DNA $=5.17$ pg, Vinogradov 1998) was introduced, since preliminary measurements revealed that the amount of DNA in nuclei of $L$. delineatus was found to be comparable with that of the $\mathrm{CE}$ standard $(\mathrm{DNA}=2.50 \mathrm{pg})$. Thus, due to a high difference in the DNA content between TE and the sunbleak red blood cells, the peaks of analyzed DNA were separated correctly to make the calculation of DNA reliable (Fig. 1A-D).

Blood from $L$. delineatus and $O$. mykiss was collected in $0.5 \mathrm{ml}$ of $\mathrm{Ca}^{2+}$ - and $\mathrm{Mg}^{2+}$-free HBSS 

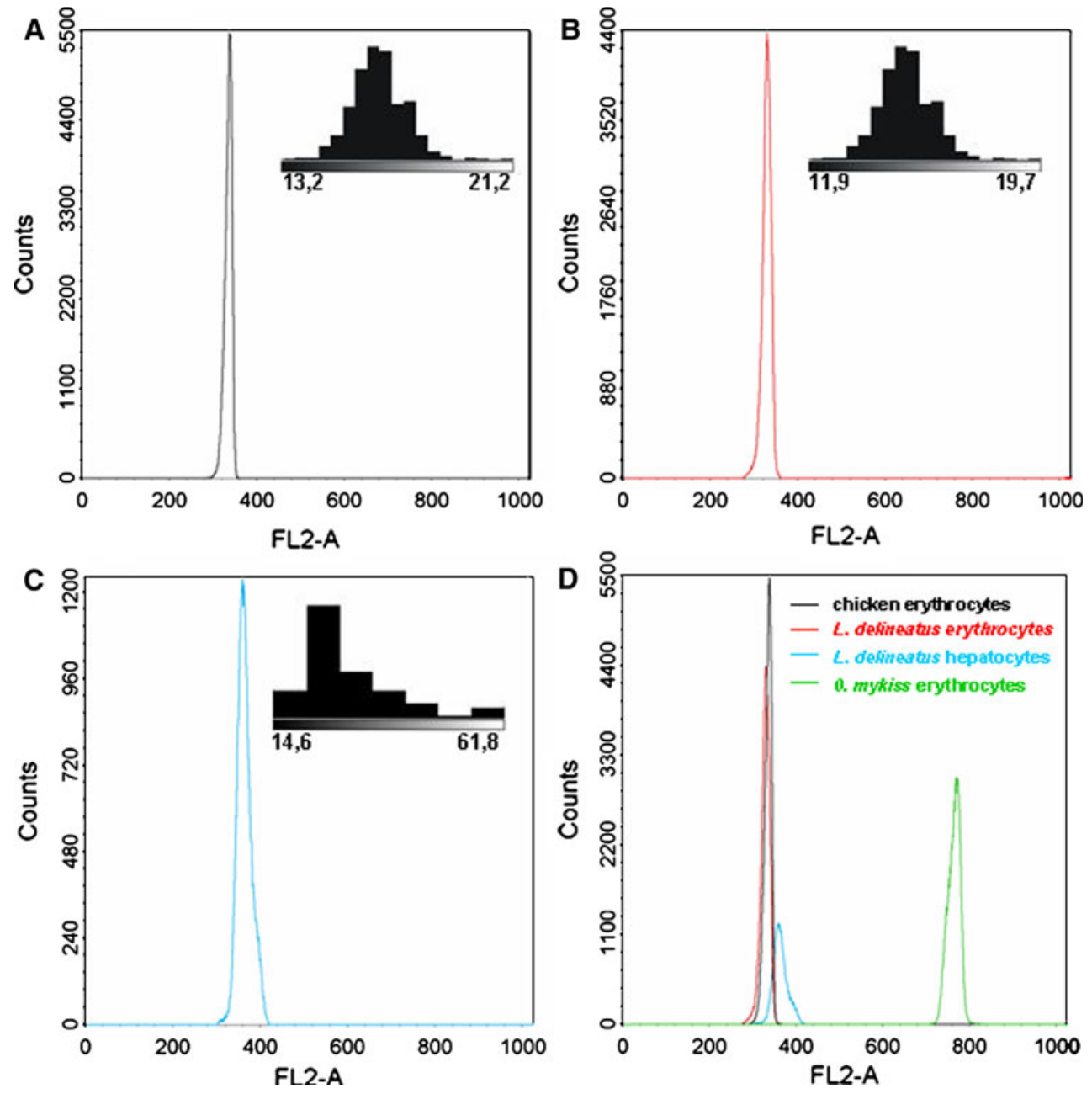

Fig. 1 Three representative histograms of the DNA-associated PI fluorescence from Leucaspius delineatus (B and $\mathbf{C})$ compared with G0/G1 chicken peripheral blood erythrocytes (A). The inserts to these histograms present the distribution of nuclear sizes expressed as profile area in $\mu \mathrm{m}^{2}$ measured from

digital micrographs after nuclei staining with DAPI. D Summarizes the histograms of $\mathbf{A}, \mathbf{B}$, and $\mathbf{C}$ to compare those obtained after the introduction of $O$. mykiss erythrocytes as an internal standard (D)

(Hank's Balanced Salt Solution) with $0.7 \mathrm{mM}$ EDTA (cat. no. E7889, Sigma-Aldrich) after cutting the caudal peduncle close to the tail fin. Chicken blood was obtained from brachial vein. The sunbleak sample, due to the small aliquot obtained, was processed to flow cytometric analysis in non-diluted form, whereas rainbow trout and chicken blood standards of approximately $0.1 \mathrm{ml}$ were diluted 1:100 with $\mathrm{Ca}^{2+}$ - and $\mathrm{Mg}^{2+}$-free HBSS. Erythrocytes were processed simultaneously with the hepatocyte homogenate described later, beginning from the steps after liver treatment with pepsin solution.

\section{Liver samples}

After L. delineatus decapitation, small fragments of liver were dissected out and minced with scissors into small pieces $\left(<1 \mathrm{~mm}^{3}\right)$, centrifuged $(400 \times g$ for 5 min) with a small bench centrifuge (2-16 PK Sigma-Labor zentrifugen $\mathrm{GmbH}$, Osterode am Harz, Germany), and incubated for $1 \mathrm{~h}$ with pepsin solution (Pepsin A P7000, Sigma-Aldrich) (0.5\% pepsin, 3\% polyethylene glycol 8000 , PEG 8000 in $0.9 \% \mathrm{NaCl}$ $\mathrm{pH} 1.5)$ at $37^{\circ} \mathrm{C}$, agitating occasionally. Then, the specimens were dissociated mechanically by gentle homogenization in a full glass homogenizer and 
filtered through the nylon mesh $(40 \mu \mathrm{m}$, BD Falcon REF 352340). The wash solution (HBSS, cat. no. H4891, Sigma-Aldrich; 0.02\% $\mathrm{NaN}_{3}, 3 \%$ PEG 8000, Sigma-Aldrich, in HBSS) was added to $2 \mathrm{ml}$ total volume of the sample and centrifuged $\left(400 \times g, 4^{\circ} \mathrm{C}\right.$, $10 \mathrm{~min})$.

DNA analysis by flow cytometry

The pellets of all cells collected and prepared according to the protocols described earlier were suspended again in the wash solution, and an equal amount of stain medium was added to the samples $(50 \mathrm{mg} / \mathrm{ml}$ propidium iodide (PI), cat. no. P-4170, SigmaAldrich, 0.1\% Nonidet P40 cat. no. 563741, SigmaAldrich, in $0.4 \mathrm{mM}$ sodium citrate), incubated for $5 \mathrm{~min}$, and centrifuged again. A mixture of the staining solution and RNAse solution (cat. no. R 4642, SigmaAldrich) (10 mg/ml RNAse A in $4 \mathrm{mM}$ sodium citrate) was added to the pellets and kept for $15 \mathrm{~min}$ in melting ice, in darkness. The flow cytometric analysis was performed within $30 \mathrm{~min}$. The measurements were taken using FACS Calibur (BD Instruments, Franklin Lakes, N.J. USA) (argon laser $15 \mathrm{~mW}, 488 \mathrm{~nm}$ ) with at least 50,000 elements counted in a gate established for the FL2-A/FL2-W channels. Cell Quest software (BD) for acquisition and WinMDI 2.9 software (Gregori et al. 2004) for analysis were used.

\section{Protein concentration analysis}

Blood cells and liver fragments isolated from L. delineatus were lysed for $30 \mathrm{~min}$ at $4{ }^{\circ} \mathrm{C}$ with a buffer containing Tris-HCl, pH 7.5 (20 mM, Merck, Germany), sodium chloride (150 mM, Chempur, Poland), $\mathrm{Na}_{2}$ EDTA (1 mM, Sigma-Aldrich, Germany), EGTA (1 mM, Sigma, Germany), $1 \%$ Triton X-100 (Calbiochem, USA), sodium pyrophosphate (2.5 mM, POCH, Poland), $\beta$-glycerophosphate ( $1 \mathrm{mM}$, Laboratory BDH Reagent, GB). Then, the samples were mechanically homogenized and total protein content was estimated using a Micro BCA Protein Kit (Thermo Scientific, USA). One milliliter of each sample was suspended in the kit components according to the manufacturer's protocol and transferred into 96-well plates. After $3 \mathrm{~h}$ of incubation at room temperature, the absorbance of samples was measured by ELIZA Microplate Reader $\left(\mathrm{EL}_{\mathrm{x}} 808\right.$, Bio-Tek Instruments, USA), using $570 \mathrm{~nm}$ filter.
DNA extraction using the phenol/chloroform/ proteinase $\mathrm{K}$ method

Briefly, blood and liver samples were suspended in lysis buffer, treated with proteinase $\mathrm{K}(10 \mu \mathrm{g} / \mathrm{ml})$, and incubated at $55^{\circ} \mathrm{C}$ for $16 \mathrm{~h}$ and then at $95^{\circ} \mathrm{C}$ for 3 min. Next, $350 \mu \mathrm{l}$ of phenol (MP Biomedicals, USA) was added; the samples were thoroughly mixed for $30 \mathrm{~s}$ and centrifuged $\left(10,000 \mathrm{rpm}, 10 \mathrm{~min}, 22^{\circ} \mathrm{C}\right)$. The aqueous phases containing DNA were transferred to $1.5 \mathrm{ml}$ eppendorfs and washed with $300 \mu \mathrm{l}$ of phenol and chloroform (Sigma, Germany) mixture (1:1). After mixing, the samples were centrifuged $\left(10,000 \mathrm{rpm}, 10 \mathrm{~min}, 22^{\circ} \mathrm{C}\right)$ and the aqueous phase collected again. Then, $250 \mu \mathrm{l}$ of 2-propanol was added; the extracts vortexed and centrifuged $\left(12,000 \mathrm{rpm}, 22^{\circ} \mathrm{C}, 1 \mathrm{~min}\right)$. The supernatant was removed, and the pellets were resuspended in $70 \%$ ethanol and centrifuged $\left(12,000 \mathrm{rpm}, 22^{\circ} \mathrm{C}, 1 \mathrm{~min}\right)$. Finally, TE buffer $(10 \mathrm{mM}$ Tris- $\mathrm{HCl}, \quad 1 \mathrm{mM}$ $\mathrm{Na}_{2}$ EDTA) was used to dissolve DNA pellets, and the amount of DNA assessed spectrometrically using NanoDrop ${ }^{\mathrm{TM}_{2}} 2000$ (ThermoSCIENTIFIC, USA). DNA content was calculated in nanogram per microgram of protein.

Examination of mitochondria by flow cytometry

Mitochondria were stained with fluorescent dye MitoTracker Deep Red (Molecular Probes, USA) that emits 662-nm light when accumulated in mitochondria. Hepatocytes isolated from $L$. delineatus were centrifuged $\left(400 \times g, 5 \mathrm{~min}, 22^{\circ} \mathrm{C}\right)$ and labeled with $250 \mathrm{nM}$ solution of MitoTracker Deep Red in HBSS for $30 \mathrm{~min}$ in darkness. After washing with HBSS, the cells were examined using a flow cytometer at $633-\mathrm{nm}$ excitation by red diode laser, and the fluorescence signal was detected at FL4-H channel. Next, the cells were centrifuged $\left(400 \times g, 5 \mathrm{~min}, 4^{\circ} \mathrm{C}\right)$, treated with a mixture of the DNA staining solution containing propidium iodide as described earlier, and analyzed again in the flow cytometer.

Cell size analysis by flow cytometry

The sizes of the sunbleak erythrocytes and dissociated hepatocytes were determined using living cells by means of flow cytometric analysis. As the standard, equal volumes of latex beads with 
increasing diameter (4, 6, 10 and $15 \mu \mathrm{m}$;cat. no. F13838, Invitrogen, USA) were mixed together in $1 \mathrm{ml}$ of $\mathrm{Ca}^{2+}$ - and $\mathrm{Mg}^{2+}$-free HBSS and analyzed at FSC channel with parameters established for the particular cell type. Then, the values of the peak positions at FSC channel histograms were extracted for all sizes of the latex beads to draw a calibration function. On that basis, the diameters of erythrocytes and those of hepatocytes were calculated after extractions of the FSC channel values characteristic for both cell types.

Nucleus size examination by fluorescence microscopy

To calculate the sizes of nuclei in the sunbleak samples, living cells were suspended in HBSS and stained in darkness with DAPI $(0.5 \mu \mathrm{g} / \mathrm{ml}$ solution in HBSS, cat. no. D9564, Sigma-Aldrich) for $25 \mathrm{~min}$ at room temperature. Then, $5 \mu \mathrm{l}$ of cell suspension was placed on a clean microscopic slide and mounted with a cover slip. The fluorescent images were digitally captured with a confocal microscope (Zeiss LSM510 META, Carl Zeiss Microimaging GmbH, Jena, Germany) and analyzed in Image J 1.42 software to obtain the perimeter and area values from their profiles. The diameters were estimated from the areas.

\section{Nucleoplasmic ratio calculation}

Nucleoplasmic ratio (NC ratio) of $L$. delineatus erythrocytes and that of hepatocytes were estimated according to the formula $\mathrm{NC}=\frac{V_{N}}{V_{C}-V_{N}}$ (Hertwig 1903), where $V_{N}$ is the nuclear volume and $V_{C}$ the volume of the cell calculated on the basis of the results obtained from the experiments described previously. We approximated the shapes of cells and nuclei to spheres; thus, the average diameter of both was estimated and their volumes calculated.

\section{Results}

The sampled population contained 20 diploid $(2 \mathrm{n}=50)$ individuals of Leucaspius delineatus. Figure $1 \mathrm{~B}$ and $\mathrm{C}$ shows representative histograms of the DNA-associated PI fluorescence from the sunbleak erythrocytes and hepatocytes, respectively, showing the DNA contents of diploid G0/G1 phase. Figure 1A shows FL2-A histogram from the CE standard $(\mathrm{DNA}=2.5 \mathrm{pg})$, showing that the fluorescence peaks for fish and chicken DNA-associated PI are in proximity. For that reason, the rainbow trout erythrocytes $(\mathrm{DNA}=5.17 \mathrm{pg})$ were used as the second standard, since its fluorescence peak is shifted to the right on the FL2-A axis (Fig. 1D). Noteworthy is the low standard deviation (2\%) and relatively low coefficient of variation (CV) $(2.5 \%)$ for both erythrocytes and hepatocytes (Table 1).

The calculation of the DNA amount based on the CE standard (Vindelow et al. 1983) revealed that the diploid nuclei of the sunbleak's erythrocytes and hepatocytes have $2.47 \pm 0.05 \mathrm{pg}$ and $2.70 \pm 0.07$ $\mathrm{pg}$, respectively. The ratio between erythrocyte DNA and hepatocyte DNA is 0.91 . However, when the TE standard was used for estimation, the DNA values for erythrocytes and hepatocytes were slightly lower$2.25 \pm 0.06 \mathrm{pg}$ and $2.46 \pm 0.06 \mathrm{pg}$, respectively. The amount of DNA isolated from erythrocytes and hepatocytes was 31 and $38 \mathrm{ng} / \mu \mathrm{g}$ protein, respectively. The ratio between erythrocyte DNA and hepatocyte DNA from these samples is 0.82 (Table 1).

The size of erythrocyte nuclei of $L$. delineatus expressed as modal values was $4.4 \mu \mathrm{m}$ for diameters,

Table 1 The results of flow cytometric and spectrophotometric analysis of DNA content in Leucaspius delineatus erythrocytes and hepatocytes (mean \pm SD) calculated using two standards: chicken and rainbow trout erythrocytes or in relation to protein content

\begin{tabular}{|c|c|c|c|c|c|c|c|}
\hline \multirow{2}{*}{$\begin{array}{l}\text { Leucaspius } \\
\text { delineatus }\end{array}$} & \multicolumn{2}{|c|}{ DNA content (pg) (CV\%) } & \multirow{2}{*}{$\begin{array}{l}\text { DNA content } \\
\text { (ng/ } \mu \mathrm{g} \text { protein) } \\
\text { Isolated DNA }\end{array}$} & \multicolumn{2}{|c|}{ Size of nuclei } & \multirow{2}{*}{$\begin{array}{l}\text { Cell diameter } \\
(\mu \mathrm{m})\end{array}$} & \multirow[t]{2}{*}{$\mathrm{NC}$ ratic } \\
\hline & Chicken standard & O. mykiss standard & & $\begin{array}{l}\text { Perimeter } \\
(\mu \mathrm{m})\end{array}$ & $\begin{array}{l}\text { Area } \\
\left(\mu \mathrm{m}^{2}\right)\end{array}$ & & \\
\hline Erythrocytes & $2.47 \pm 0.05(2.0 \%)$ & $2.25 \pm 0.06(2.5 \%)$ & 31.1 & 14.2 & 15.2 & $5.1 \pm 0.2$ & 2.51 \\
\hline Hepatocytes & $2.70 \pm 0.07(2.5 \%)$ & $2.46 \pm 0.06(2.5 \%)$ & 38.4 & 20.2 & 21.4 & $22.3 \pm 5.0$ & 0.08 \\
\hline
\end{tabular}

The size of nuclei from both types of cells is expressed as modal/average perimeter and area (or diameter) as assessed by image analysis of DAPI-stained micrographs. A cell size is presented as the mean \pm SD diameter, since calculated on the basis of calibration bead's diameters. NC is the nuclear-to-cytoplasm volume ratio 


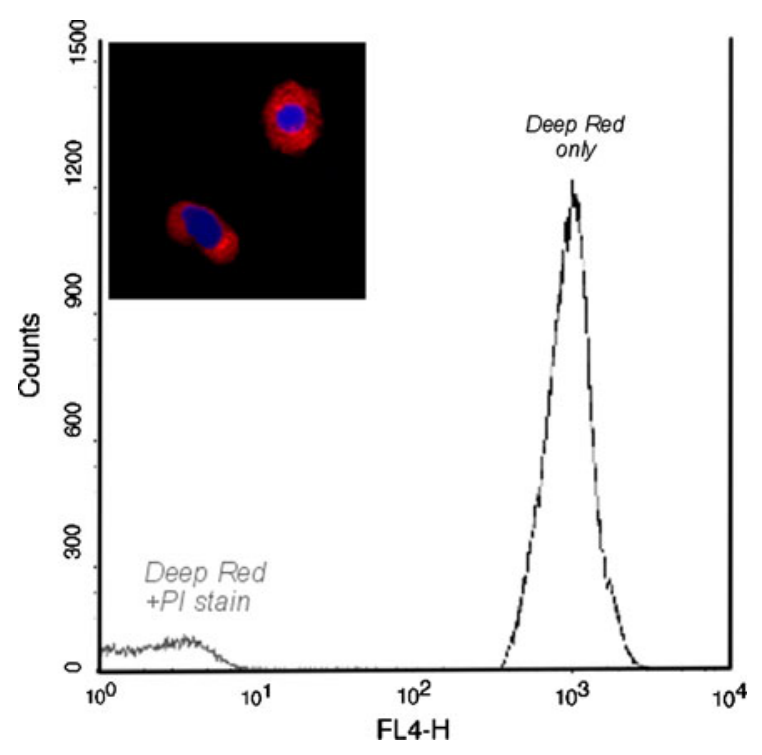

Fig. 2 Representative histogram of mitochondrial staining with MitoTracker Deep Red (Deep Red only) or both DeepRed and propidium iodide (Deep Red + PI stain). The high intensity of Deep Red fluorescence at FL4-H shows positive staining of mitochondria in hepatocytes. After PI staining, the fluorescence of Deep Red disappeared showing the absence of mitochondria in hepatocyte samples. The insert shows two isolated hepatocytes stained with MitoTracker Deep Red (red) to demonstrate the presence of mitochondria in the cells. The nuclei were counter-stained with DAPI. Magnification: $400 \times$

$14.2 \mu \mathrm{m}$ for their perimeters, and $15.2 \mu \mathrm{m}^{2}$ for areas, while the values of diameters, perimeters and areas calculated for the hepatocytes were 5.2, $20.2 \mu \mathrm{m}$ and $21.4 \mu^{2}$, respectively (Fig. 1, inserts). Moreover, the mean diameter of the sunbleak erythrocytes was $5.1 \pm 0.2 \mu \mathrm{m}$, whereas that for the liver cells was $22.3 \pm 5.0 \mu \mathrm{m}$. The nucleoplasmic ratio of L. delineatus erythrocytes was determined as 2.51 and was significantly higher than that calculated for hepatocytes -0.08 (Table 1 ).

The analysis of mitochondria in hepatocytes using specific stain (MitoTracker Deep Red) has shown their presence in freshly prepared liver samples (Fig. 2, insert). However, when the samples were treated with Nonidet P40, the lack of fluorescence demonstrated the absence of mitochondria in the samples prepared to DNA analysis in flow cytometer.

\section{Discussion}

Comprehensive studies of the genome size of teleost fish have been published in the past (Hinergardner
1968; Hinergardner and Rosen 1972; Vinogradov 1998; Tiersch et al. 1989). The method used in the present study was based on fresh unfixed material obtained from fish directly collected from water. This is important as precision and reproducibility of the measurements may depend on chromatin condensation. Processing specimens with any fixative solutions before flow cytometric analysis might interfere with the DNA structure what could result in a shift of PI fluorescence intensity. Specimen preservation with ethanol or fixation with formalin results in a large $\mathrm{CV}$, and hence, it decreases the ability to detect near diploid aneuploidy (Hedley et al. 1983; MacIntire et al. 1987). This may be due to morphological changes in chromosome structure, which might cause non-homogeneous binding of fluorescent dye to DNA, resulting in peak shifting.

We propose that the higher value of CV $(2.5 \%)$ found after the analysis of liver cell nuclei in relation to erythrocytes $(2.0 \%)$, as well as the asymmetry of the fluorescence peaks, might be characteristic for cells rich in cytoplasm as are hepatocytes. It seems that remnants of cytoplasm contaminate the nuclei, cause clumping and non-specific staining as we observed with a fluorescence microscope (not shown). Further, it influences fluorescence intensity detected by the cytometer leading to peak broadening.

It is noteworthy that, in our study, the DNA content of hepatocyte nuclei was found to be higher than that of erythrocyte nuclei. The ratio between erythrocyte DNA and hepatocyte DNA was 0.91. We excluded the possibility that the dispersion of chromatin in liver nuclei may be responsible for this difference as was suggested by Vinogradov (1998). However, to verify that the observed difference in DNA content between the cell types reflects a real difference, we measured the amount of DNA isolated from RBC and liver samples. The ratio found (0.82) was very close to that estimated with flow cytometry. Thus, the variability in affinity for stain and consequently in fluorescence intensity between these two cell types was not due to a difference in chromatin dispersion. We propose that the most plausible explanation is the presence of supernumerary chromosomes. The occurrence of supernumerary chromosomes was first reported in a teleost fish by Pauls and Bertollo (1983). Since then, several cases of supernumerary chromosomes or B chromosomes have been reported in various fish species (Feldberg and Bertollo 1984; Falco et al. 1984; Foresti et al. 1989; Valcarcel et al. 1993). These findings, however, were 
limited to the analysis of karyotypes of the fish used in these studies in which the analysis of DNA quantity was not carried out. Possession of additional chromosomes may help the liver cells to deal with toxins more effectively. In young animals, the liver of diploids has two sets of chromosome in each cell. As the animal ages, the number of cells with an abnormal quantity of chromosomes may increase, making the liver cells triploid or even tetraploid. However, liver cells may eliminate additional chromosomes to maintain a "close-to-diploid number" so that only some cells retain extra chromosomes. The presence of an extra chromosome may help the liver withstand assaults by toxins or may change the rate at which the liver breaks down toxic chemicals present in the water.

The possibility that mitochondrial DNA may contribute to the results obtained was excluded from flow cytometric analysis of genomic DNA in hepatocytes. We specifically stained mitochondria with MitoTraker Deep Red in freshly prepared liver cells and cells gently treated with detergent (Nonidet P40) that solubilizes cell components with the exception of nuclei. This showed that no mitochondria were present in specimens that we used to estimate the genomic DNA value in hepatocytes.

In conclusion, this study fills a gap in the literature by providing information on the genome size of one very popular and expansive teleost Leucaspius delineatus (Heckel, 1843). It did not show significant differences in DNA content between erythrocytes and hepatocytes nuclei, which demonstrates the absence of polyploidy in the fish liver under investigation.

Acknowledgements We thank Professor Elżbieta Pyza, the Chief of the Department of Cytology and Histology, for providing the facilities used in this study and hospitality for one of us (WK). We are grateful to Professor N. J. Severs for his kind correction of our English and two anonymous reviewers for their stimulated suggestions.

Open Access This article is distributed under the terms of the Creative Commons Attribution Noncommercial License which permits any noncommercial use, distribution, and reproduction in any medium, provided the original author(s) and source are credited.

\section{References}

Boron A (1994) Use of erythrocyte measurements to detect natural triploids of spined loach Cobitis taenia (L.). Cytobios 78:197-202
Castillo-Davis CI, Bedford TB, Hartl DL (2004) Accelerated rates of intron gain/loss and protein evolution in duplicate genes in human and mouse malaria parasites. Mol Biol Evol 21:1422-1427

Ciudad J, Cid E, Velasco A, Lara JM, Aijon J, Orfa A (2002) Flow cytometry measurement of the DNA contents of G0/ G1 diploid cells from three different teleost fish species. Cytometry 48:20-25

Falco JN, Moreira-Filho O, Bertollo LAC (1984) An additional chromosome in two fish species. Rev Brasil Genet 7(I):109-118

Feldberg E, Bertollo LAC (1984) Discordance in chromosome number among somatic and gonadal tissue cells of Gymnogeophagus balzani (Pisces, Chichlidae). Res Brasil Genet VII(4):639-645

Fenerich PC, Foresti F, Oliveira C (2004) Nuclear DNA content in 20 species of Siluriformes (Teleostei; Ostariophysi) from the Neotropical region. Genet Mol Biol 21:47-54

Foresti F, Almeida-Toledo LF, Toledo SA (1989) Supernumerary chromosome system. C-banding pattern characterization and multiple nucleolus organizer regions in Moenkhausia sanctafilomenae (Pisces characidae). Genetica 79:107-114

Gregori G, Ragheb K, Robinson JP (2004) Introduction to WinMDI2.8 (J. Trotter 1993-1998) for the analysis of flow cytometry listmode data files. Purdue University Cytometry Laboratories, West Lafayette

Gregory TR, Nicol JA, Tamm H, Kullman B, Kullman K, Leitch IJ, Murray BG, Kapraun DF, Greilhuber J, Bennett MD (2007) Eukaryotic genome size databases. Nucl Acids Res 35:D332-D338

Hedley DW, Friedlander ML, Taylor IW, Rugg CA, Musgrove EA (1983) Method for analysis of cellular DNA content of paraffin embedded pathological material using flow cytometry. J Histochem Cytochem 31:1333-1335

Hertwig R (1903) Über die Korrelation von Zell und Kerngrösse und ihre Bedeutung für die geschlechtliche Differenzierung und die Teilung der Zelle. Biol Centralbl 23:49-62

Hickey AJR, Clements KD (2005) Genome size evolution in New Zealand triplefin fishes. J Heredity 96:356-362

Hinergardner R (1968) Evolution of cellular DNA content in teleost fishes. Am Nat 102:517-523

Hinergardner R, Rosen DE (1972) Cellular DNA content and the evolution in teleostean fishes. Ame Nat 951:621-644

Homatowska A, Witaszek J, Adamowicz A (2002) Hematological indices and circulating blood picture in the sunbleak Leucaspius delineatus (Haeckel, 1843). Zool Pol 47:57-68

Juchno D, Lackowska B, Boron A, Kilarski W (2010) DNA content of hepatocyte and erythrocyte nuclei of the spined loach (Cobitis taenia L.) and its polyploid forms. Fish Physiol Biochem 36:523-529

Lamatsch DK, Steinlein C, Schmid M, Schartl M (2000) Noninvasive determination of genome size and ploidy level in fishes by flow cytometry: detection of triploid Poecillia Formosa. Cytometry 39:91-95

Le Comber SC, Smith C (2004) Polyploidy in fishes: pattern and processes. Biol J Linnean Soc 82:431-442

Lynch M, Force A (2000) Gene duplication and the origin of interspecific genome incompatibility. Am Nat 156: 590-605 
MacIntire TL, Goldey SH, Beenson NA, Braylan RC (1987) Flow cytometric analysis of DNA in cells obtained from depariffinized formalin fixed lymphoid tissues. Cytometry 8:474-478

Pauls S, Bertollo LAC (1983) Evidence for a system of a supernumerary chromosomes in Prochilodus scrofa Steindachner 1881 (Pisces, prochilodontidae) Caryologia, 34(4):307-314

Peruzzi S, Chatain B (2003) Induction of tetraploid gynogenesis in the European sea bass (Dicentrarchus labrax L.). Genetica 119:225-228

Pie MR, Torres RA, Brito DMA (2007) Evolution of genome size in fishes: a phylogenetic test of the Hinegardner and Rosen hypothesis. Genetica 131:51-58

Swarup H (1959) Effects of triploidy on the body size, general organization and cellular structure in Gasterosteus aculeatus (L.). J Genet 56:143-155
Taylor JS, Van de Peer Y, Meyer A (2001) Genome duplication, divergent resolution and speciation. Trends Genet 7:299-301

Tiersch TR, Chandler RW, Kallman KD, Wachtel SS (1989) Estimation of nuclear DNA content by flow cytometry in fishes of genus Xiphohporus. Comp Biochem Physiol 94 B:465-468

Valcarcel A, Brunner P, Maggese MC (1993) B-chromosome polymorphism in the south American catfish, Rhamdia sapo. Aquaculture 110:111-118

Vindelow IL, Christensen IJ, Nissen NJ (1983) Standardization of high-resolution flow cytometric DNA analysis by the simultaneous use of chicken and trout blood cells as internal reference standards. Cytometry 3:328-331

Vinogradov AE (1998) Genome size and GC-percent in vertebrates as determined by flow cytometry: the triangular relationship. Cytometry 31:100-109 